\title{
Results of the application of pulmonary physiotherapy in a 38-year-old post-COVID- 19 patient after severe pneumonia and type 2 diabetes mellitus
}

\section{Resultados de la aplicación de fisioterapia pulmonar en paciente post-COVID-19 de 38 años de edad post neumonía grave y diabetes mellitus tipo 2}

\author{
VÁZQUEZ-CHACÓN, Verónica†*, SÁNCHEZ-BARRERA, Eréndira and CHÍO-AUSTRIA, Rosa \\ María
}

Universidad Politécnica de Pachuca, Hospital Psiq. Dr. Adolfo M. Nieto Tepexpan, Mexico.

ID $1^{\text {st }}$ Author: Verónica, Vázquez-Chacón / ORC ID: 0000-0003-2002-6876, Researcher ID Thomson: V-5652-2018, arXiv Author ID: Veronica_\#77, PubMed Author ID: Vazquez_v

ID $1^{\text {st }}$ Co-author: Eréndira, Sánchez-Barrera / ORC ID: 0000-0003-2466-6977, arXiv Author ID: Erendiris_28, PubMed Author ID: Sanchez_28

ID $2^{\text {nd }}$ Co-author: Rosa María, Chío-Austria / ORC ID: 0000-0003-2354-0731, arXiv Author ID: Chío 8789, PubMed Author ID: rosa_ma

DOI: $10.35429 / J P .2021 .13 .5 .11 .21$

Received January 20, 2021; Accepted June 30, 2021

\begin{abstract}
Objectives General: to create a Pulmonary Physiotherapy Program to ensure that the patient with severe or severe post-COVID-19 disease with pulmonary compromise and, with oxygen supplementation, reaches their maximum functional capacity, which in turn facilitates the maximum degree of autonomy and improvement in health-related quality of life. Specific objectives: Minimize the sensation of dyspnea. Improvement of ventilatory mechanics, oxygenation and reduction of supplemental oxygen. Increased strength of respiratory muscles. Promote functional independence through improvement in cardiopulmonary capacity. Evaluate the impact of the program using the quality of life assessment scale. Methodology: Case report, quantitative, longitudinal and prospective. Contribution: The scientific contribution of this article focuses on the knowledge of nonpharmacological treatment (Pulmonary Physiotherapy) in the post-COVID-19 and type 2 Diabetes Mellitus patient.
\end{abstract}

Pulmonary physiotherapy, Post COVID-19

\begin{abstract}
Resumen
Objetivo General: Crear un Programa de Fisioterapia pulmonar para conseguir que el paciente con enfermedad post COVID-19 grave o severa con compromiso pulmonar y, con suplencia de oxígeno, alcance su máxima capacidad funcional, a su vez, le faciliten el máximo grado de autonomía y mejoría en la calidad de vida relacionada con la salud. Los objetivos específicos: Disminuir al máximo la sensación de disnea. Mejora de la mecánica ventilatoria, oxigenación y disminución de oxígeno suplementario. Aumento de fuerza de musculatura respiratoria. Promover la independencia funcional por medio de la mejoría en capacidad cardiopulmonar. Evaluar el impacto del programa por medio de escala de valoración de calidad de vida. Metodología: Reporte de caso, de tipo cuantitativo, longitudinal y prospectivo. Contribución: El aporte científico del presente artículo se centra en el conocimiento del tratamiento no farmacológico (Fisioterapia Pulmonar) en el paciente post-COVID-19 y Diabetes Mellitus tipo 2.
\end{abstract}

Fisioterapia pulmonar, Post COVID-19

Citation: VÁZQUEZ-CHACÓN, Verónica, SÁNCHEZ-BARRERA, Eréndira and CHÍO-AUSTRIA, Rosa María. Results of the application of pulmonary physiotherapy in a 38-year-old post-COVID-19 patient after severe pneumonia and type 2 diabetes mellitus. Journal of Physiotherapy and Medical Technology. 2021. 5-13:11-21.

\footnotetext{
* Author Correspondence (E-mail: veronicavazquez@upp.edu.mx).

$\dagger$ Researcher contributing as first author.
} 


\section{Introduction}

COVID-19 (coronavirus disease 2019) also known as new coronavirus disease is caused by severe acute respiratory syndrome coronavirus 2 (SARS-CoV2) [1].

It produces flu-like symptoms including fever, cough, dyspnea, myalgia, and fatigue [1].

In severe cases it is characterized by producing pneumonia, acute respiratory distress syndrome, sepsis and septic shock leading to about $3 \%$ of those infected to death, although the mortality rate is at $4.48 \%$ and rising [1].

Several studies also report fatigue and dyspnea as persistent or prolonged symptoms in patients who had both severe and mild COVID19 [8].

Of the reported active cases in the State of Hidalgo, $68 \%$ correspond to ambulatory cases.

On the other hand, type 2 diabetes mellitus (previously called non-insulindependent or adult-onset diabetes) is due to the fact that the body does not effectively use the insulin it produces. Most diabetics have type 2, which, to a large extent, is due to excess weight and lack of physical activity [4].

Pulmonary Physiotherapy is part of the multidisciplinary treatment for the care of postCovid-19 patients, providing benefits in decreasing the sensation of dyspnea, improvement of ventilatory mechanics and quality of life, among others.

Close follow-up, through a Pulmonary Physiotherapy program, allows the patient to reduce the risk of disability.

\section{COVID-19}

\section{Etiology}

The pathogen identified is new virus of the Coronaviridae family, initially-and temporarilycalled novel coronavirus (2019-nCoV), and finally SARS-CoV-2, causing COVID-19 (Coronavirus Disease 2019) [6].

\section{Epidemiology}

In America, about 76,585,479 cases of persons diagnosed with COVID-19 and a total of $1,999,971$ deaths as of July 29, 2020. With a case fatality rate of 9.3 . With a higher cumulative incidence rate of 10,962 [4].

In Mexico, as of July 25, there are 109,279 active cases, 149,144 suspected cases and 238,424 deaths. In the state of Hidalgo, 96\% of the territory is at high risk with more than 2,000 cases in each municipality.

\section{Pathogenesis}

The pathogenesis of COVID-19 begins when the virus, by means of glycoprotein $\mathrm{S}$, binds to the cellular receptor $\mathrm{hACE}_{2}$ and then fuses with the respiratory epithelial cell membrane, entering it by endocytosis. Upon entering the cytoplasm of the cell. From the first contact, an immune response is triggered, which can be divided into two main phases. The first phase develops during the incubation period, which is usually 1 to 14 days (average 5 days) and in the early stages of the symptomatic period. In the second phase of the immune response, the cellular response increases considerably, causing severe lesions that may contribute to the death of the patient. The course of the disease in three stages [6]:

(a) Stage I(mild)-early infection.

(b) Stage II (moderate)-with pulmonary involvement without hypoxia (IIa) or with hypoxia (IIb).

\section{(c) Stage III (severe)-systemic hyperinflammation; each with characteristic pathophysiologic events and clinical manifestations.}

The form of direct transmission is by droplets (>5 microns) or aerosols $(<5 \mu \mathrm{m})$, which are going to be transmitted via upper respiratory route from symptomatic patients to another individual [6].

Clinical manifestations, progression and complications

The spectrum of clinical manifestations is broad and still unclear, with a variety of symptoms reported in the range of mild to severe and critical illness, with cases resulting in death.

VÁZQUEZ-CHACÓN, Verónica, SÁNCHEZ-BARRERA, Eréndira and CHIIO-AUSTRIA, Rosa María. Results of the application of pulmonary physiotherapy in a 38-year-old post-COVID-19 patient after severe pneumonia and type 2 diabetes mellitus. Journal of Physiotherapy and Medical Technology. 2021 
The most reported manifestations are fever $(85 \%)$, dry cough $(50-80 \%)$, myalgias or fatigue (69.6\%), dyspnoea (20-40\%) and pneumonia; while less common symptoms include headache, diarrhea, hemoptysis, rhinorrhea and productive cough. Patients with mild symptoms usually recover after one week, while severe cases experience progressive respiratory failure due to alveolar damage by the virus, which can lead to death. Mortality is higher in middle-aged and elderly patients with pre-existing conditions (diabetes mellitus, hypertension, heart disease, cirrhosis, cancer, and others) [6].

The main clinical forms recognized by WHO are as follows: Uncomplicated disease (minimally symptomatic), Uncomplicated uncomplicated lower respiratory tract infection (mild pneumonia) and Severe pneumonia: presence of productive cough, with fever, nasal flaring, tachypnea (respiratory rate > 30 breaths/min, limitation of thoracic expansibility, with moist rales (crackles), or presenting as atypical pneumonia, but with signs of severity. There may be intercostal or suprasternal retractions, central cyanosis, with $\mathrm{SpO}_{2}$ with room air [1]. According to the "COVID-19 Diagnosis and Treatment Guideline (version 7.0)" of the Health Commission of the People's Republic of China, there are four stages for COVID-19, described as follows: (a) Mild Disease, (b) Moderate Disease, (c) Severe Disease, with the presence of 1 of the following criteria: (1) dyspnea, respiratory rate $\geq 30$ times/min; (2) oxygen saturation $\leq 93 \%$ at rest; (3) $\mathrm{PaO} 2 / \mathrm{FiO} 2 \leq 300 \mathrm{mmHg}$. Patients with significant radiological progression of pulmonary infiltrates, $>50 \%$ within $24-48$ hours; (d) Critical Illness. Long-term complications among survivors of SARS-CoV-2 infection with clinically significant COVID-19 disease are not yet available. Further long-term follow-up clinical studies are needed [6]

\section{Diagnosis}

Routine confirmation of COVID-19 cases is based on detection of virus nucleic acid (RNA) by real-time reverse transcriptase-polymerase chain reaction (rRT-PCR) assays [6].

\section{Treatment}

It is recommended to read Recommendations for the treatment of SARS-CoV2 condition, causative agent of COVID-19, Version 6 July 2020 and Clinical guide for the treatment of COVID-19 in Mexico, Inter-institutional consensus version 02 August 2021.11,12].

\section{Pulmonary rehabilitation}

Pulmonary rehabilitation (PR) is defined, according to the latest update of the American Thoracic Society and the European Respiratory Society, as a comprehensive intervention, based on comprehensive patient assessment, followed by tailored therapies, including, but not limited to, physical training, education, and habit modification, designed to improve the physical and psychological status of persons with chronic respiratory disease (CRD) and promote longterm adherence to healthy habits [6].

The three main components of a health care system-prevention, treatment, and rehabilitation-are equally important in any serious illness, and COVID-19 infection is no exception [6].

The rapid introduction and continued availability of pulmonary rehabilitation services is critical for these patients, which is why both the World Health Organization (WHO) Regional Office for the Americas and the Pan American Health Organization (PAHO) recommend, based on the precept that rehabilitation improves health outcomes for patients with severe COVID-19 [6].

The pulmonary rehabilitation program goals put forward globally have been developed based on referrals from health care personnel who have worked with these patients in the first line of care for the disease; primarily rehabilitation specialists in China and, more recently, on the consensus issued by the American Thoracic Society-ats) and the European Respiratory Society-ers, who have developed practical and feasible pulmonary rehabilitation guidelines for COVID-19 survivors.

A PR program can be developed at the inpatient or outpatient level [6], inpatient or outpatient setting [6]. Figure 1. 
The program's multidisciplinary team is composed of different health professionals, motivated, trained and with complementary functions, focused on the physical and social care of patients, who provide individualized care adapted to the disease, its behaviour and evolution, with emphasis on education for selfcare, psychosocial support for social integration and improvement of the quality of life of patients and their families, with evaluation and follow-up of the results obtained [6].

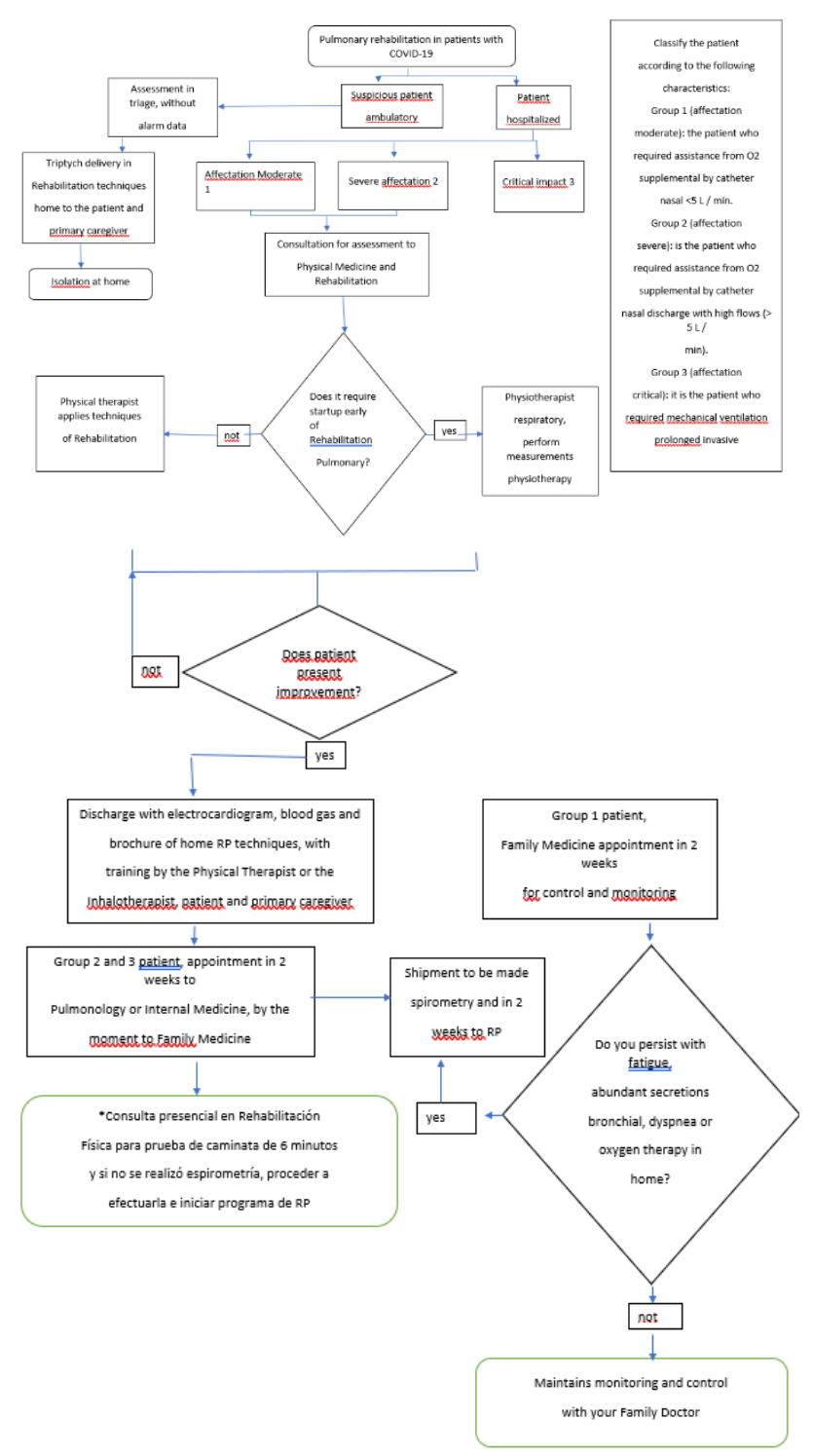

Figure 1 Pulmonary rehabilitation algorithm Source: Respiratory physiotherapist [11]

For his part, the physiotherapist oversees the functions listed below. He/she trains, coaches, educates the patient and caregivers individually and in groups on physiotherapy techniques, the use of peripheral and respiratory muscles, respiratory incentives, different types of inhalers, peak flow meters and oxygen therapy, as well as noninvasive mechanical ventilation and performs pulmonary function tests [6]
Participates in aerobic and resistance exercise training.

Monitors cardiorespiratory variables during general physical training [6].

Duration and components of pulmonary rehabilitation program for COVID-19 survivors.

Based on the ATS/ERS recommendations, a program duration of eight to twelve weeks is proposed, during which twentyfour to thirty-six sessions should be carried out, with a frequency of three to five sessions per week and a minimum duration of one hour per session.6]

The program should include, fundamentally, an initial specialized medical assessment that includes cardiorespiratory and functional physical examination, as well as different paraclinical tests, aerobic training, peripheral muscle strength training, respiratory training, patient and family education, psychosocial support, nutritional support, occupational therapy and speech therapy [6]:

Initial specialized medical and physiotherapeutic assessment.

Prior to admission to pulmonary rehabilitation, the diagnosis of the respiratory disease, its severity and possible resulting limitations should be determined, and attention should be paid to the presence of signs and symptoms of respiratory insufficiency that may decompensate with exercise. Also, the performance of a complete medical history relating pre-existing comorbidities (emphasis on previous metabolic and cardiorespiratory diseases), a detailed cardiopulmonary physical examination and application of scales for assessment of fatigue, risk of falls, quality of life and functional independence [6].

The following studies are recommended paraclinical prior to program entry [6]:

Complete blood count.

Chest radiography.

High-resolution computed tomography of the chest (Tacar).

\section{- $\quad$ Spirometry.}

VÁZQUEZ-CHACÓN, Verónica, SÁNCHEZ-BARRERA, Eréndira and CHÍO-AUSTRIA, Rosa María. Results of the application of pulmonary physiotherapy in a 38-year-old post-COVID-19 patient after severe pneumonia and type 2 diabetes mellitus. Journal of Physiotherapy and Medical Technology. 2021 
Respiratory muscle strength measurement (Pimax-Pemax).

To standardize the pulmonary rehabilitation program, they are listed below to apply them as a measure of activity prescription and outcome measure.

Medical Research Council (mrc) dyspnea scale for assessing dyspnea in activities of daily living. This scale is intended to allow the patient to quantitatively grade his or her own dyspnea in a simple, visual way.

Borg scale for quantifying dyspnea and fatigue during physical exertion. It measures the entire range of exertion an individual perceives with exercise versus activities of daily living.

Six-minute walk test/two-minute walk test: is a constant-load stress test that measures the distance a person can walk in six minutes and assesses patients' functional capacity [6].

\section{Aerobic exercise training}

Aerobic exercise is the physical training modality most used in pulmonary rehabilitation programs, based on a submaximal effort that is maintained for prolonged periods of time using large muscle masses. Training with arm ergometers, static bicycle or treadmill are the examples of exercise most used in pulmonary rehabilitation: the use of machines such as the elliptical or stair climber is left for patients with a higher functional capacity [6].

It is recommended to perform this exercise at least three times a week with a duration of twenty to thirty minutes according to the functional capacity of each patient, with a low intensity $(40 \%$ to $60 \%$ of the maximum fc and perception of mild to moderately mild exercise on Borg scale), at least, during the first two to three weeks, and increase its intensity according to the patient's tolerance until achieving, a moderate intensity $(70 \%$ to $80 \%$ of the maximum $\mathrm{fc}$ and perception of moderately strong exercise on Borg scale). In addition, it is important to maintain strict control of oxygen saturation $\left(\mathrm{SaO}_{2}\right)$ above $90 \%$, otherwise the use of supplemental $\mathrm{O}_{2}$, monitoring of dyspnea and mucocutaneous pallor associated with physical exertion is indicated $[6,9]$.

\section{Muscle strength training}

This exercise should be performed at least twice a week per week, starting the work with low loads, beginning with series of ten repetitions and mild to moderate intensity per muscle group, with an average duration of two minutes per series and increasing the workload by $5 \%$ to $10 \%$ each week. Dumbbells, adjustable weights with Velcro, medicine balls or elastic bands can be used for this activity.

Additionally, with patients who have impaired balance, intervention with an emphasis on strengthening lower limb musculature and, if possible, proprioception work is recommended [6].

Work 1-3 muscle groups with a load of 8-12 repetitions, with 2-minute training intervals. The frequency would be 2-3 sessions/week for a minimum period of 6 weeks, increasing by $5-10 \%$ load/week [9].

\section{Respiratory muscle training}

It is mainly aimed at patients presenting with symptoms such as dyspnoea, wheezing, weakness for cough production and expectoration. To perform this practice, it is important to demonstrate inspiratory and/or expiratory muscle weakness.

The training is performed twice a day, with a duration of ten to fifteen minutes per session, and starting at an intensity of between $30 \%$ to $50 \%$ of the inspiratory/expiratory pressure, using easily accessible and manageable devices that allow the workload to be controlled, such as the inspirometer or the threshold device or Threshold® [6].

\section{Teaching respiratory reeducation techniques}

These techniques aim to re-educate the ventilatory pattern to make it more efficient and, thus saving energy by maximizing the use of the diaphragm. Different respiratory pattern reeducation techniques are proposed, mainly costodiaphragmatic breathing (decreases tachypnea, improves gas exchange, decreases anxiety), pursed-lip breathing (decreases tachypnea, improves gas exchange) and the hold and catch technique (improves airflow and lung expansion, favors resolution of atelectasis and respiratory clearance) [6].

VÁZQUEZ-CHACÓN, Verónica, SÁNCHEZ-BARRERA, Eréndira and CHIIO-AUSTRIA, Rosa María. Results of the application of pulmonary physiotherapy in a 38-year-old post-COVID-19 patient after severe pneumonia and type 2 diabetes mellitus. Journal of Physiotherapy and Medical Technology. 2021 


\section{Teaching relaxation techniques}

These techniques favor self-control of hyperventilation and dyspnea, hyperventilation and dyspnea, produced by the anxiety generated by the pathology itself, as well as dyspnea, so that they facilitate recovery after physical exertion and reduce energy expenditure during activities of daily living [6].

According to the Association of Respiratory Care Physiotherapists in the UK, the need for bronchial drainage techniques in SARSCOV2-infected patients may be decided if the following criteria are met: - Evidence of retention of secretions with difficulty expectorating - Ineffectiveness of cough or drainage ability [9].

\section{Active mobilization}

The Chinese Medical Rehabilitation Association together with the Chinese Respiratory Rehabilitation Committee have published recommendations for defining when and how to initiate early active mobilization in severe or critically ill COVID-19 patients [9].

\section{Diabetes mellitus}

It is defined as a heterogeneous syndrome originated by genetic-environmental interaction and characterized by chronic hyperglycemia, as a consequence of a deficiency in insulin secretion or action, which triggers acute (ketoacidosis and hyperosmolar coma), chronic microvascular (retinopathies and neuropathies) and macrovascular complications (coronary heart disease, cerebrovascular and peripheral vascular diseases).14]

\section{Etiology}

Some risk factors for developing DM 2 are: overweight; obesity; sedentary lifestyle; firstdegree relatives with diabetes; $>45$ years of age; a waist circumference greater than $80 \mathrm{~cm}$ in women, and $90 \mathrm{~cm}$ in men; risk glycemia for developing chronic complications, >111 mg/dl fasting, and $>140 \mathrm{mg} / \mathrm{dl}$ in the immediate postprandial period Having a BMI > 25 and < 29.9 implies overweight, and a BMI $>30 \mathrm{~km} / \mathrm{m}^{2}$, obesity.17]

\section{Diagnosis}

\section{Diagnostic criteria}

Fasting glucose: equal to or greater than $126 \mathrm{ml} / \mathrm{dL}$.

Casual blood glucose: equal to or greater than $200 \mathrm{mg} / \mathrm{dL}$.

Classic symptoms of diabetes: polyuria, polydipsia, polyphagia, and unexplained weight loss [16].

\section{Treatment}

\section{Drug treatment}

The pharmacological properties of these groups provide the option of initiating treatment with one of them (monotherapy), the recommended treatment, if there is no contraindication for its use, is metformin. Remember that within three months the patient should be reaching control goals (HbA1c <7). Otherwise, switch to a combination of drugs in double (group a) or triple therapy (group B).

Group A: metformin + sulfonylurea, metformin + acarbose, metformin + thiazolidinedione, metformin + meglitinide, metformin + insulin, metformin + DPP4 inhibitor, Metformin + GLP-1 agonist, sulfonylureas + acarbose, sulfonylureas + thiazolidinediones, sulfonylureas + DPP4 inhibitor, sulfonylurea + GLP-1 agonist, sulfonylurea + insulin.

Group B: metformin + sulfonylureas + glitazones or DPP 4 or insulin, metformin + DPP $4+$ sulfonylureas or glitazones or insulin, metformin + basal insulin + glitazone or DPP 4 [14].

\section{Non-drug treatment}

\section{Continuing therapeutic education}

Education is the cornerstone of treatment and is present in all services as an essential element in the comprehensive care of the diabetic patient. 
Education should be invariably maintained, identifying deficiencies, expanding knowledge to influence behavioral changes, achieving a lifestyle appropriate to the diabetic condition, is fundamental to control the disease and decrease complications.

\section{Adequate nutrition}

It is aimed at contributing to the normalization of glycemia values during 24 hours, and to favour the normalization of lipid values.

\section{Physical activity}

The immediate physiological benefits of physical activity are improved systemic insulin action from 2 to $72 \mathrm{~h}$, improved systolic rather than diastolic blood pressure, and increased glucose uptake by muscle and liver. In addition, the higher the intensity of physical activity, the more carbohydrates are utilized. Endurance physical activity decreases glucose in the first 24 h.

In the long term, physical activity maintains insulin action, glucose control, fat oxidation and lowers LDL cholesterol. If accompanied by weight loss, it is more effective in improving dyslipidemia, however, recent studies reveal that, even if it does not cause weight loss, it significantly improves glycemic control, reduces visceral adipose tissue, plasma triglycerides, improves nitric oxide levels, endothelial dysfunction and depression.

Simple habit-related measures have been shown to effectively prevent or delay the onset of type 2 diabetes. To help prevent this type of diabetes and its complications, these behaviors should be followed:

Achieve and maintain a healthy body weight; engage in at least 30 minutes of moderate-intensity physical activity most days. However, to control weight it may be necessary to increase the intensity; eat a healthy diet, free of sugar and saturated fats; and do not use tobacco, as smoking increases the risk of diabetes and cardiovascular disease. The Organization's work on diabetes is complemented by the WHO Global Strategy on Diet, Physical Activity and Health, which focuses on population-based measures to promote healthy eating and regular physical activity to reduce the growing problem of overweight and obesity worldwide [4].
Type 2 diabetes mellitus (DM2) is considered a major risk factor for an adverse outcome in patients with COVID-19 [19].

\section{Case presentation}

A 38-year-old male, diagnosed with severe postCovid stage III and type 2 diabetes mellitus, started symptoms (fever, dyspnea, desaturation up to $65 \%$ of $\mathrm{SpO}_{2}$ ) on January 6 of this year, started drug treatment for COVID-19 two days later, at home due to lack of availability of health services in the city of Pachuca de Soto Hidalgo, requiring oxygen therapy at 17 litters per minute. Figure 2.

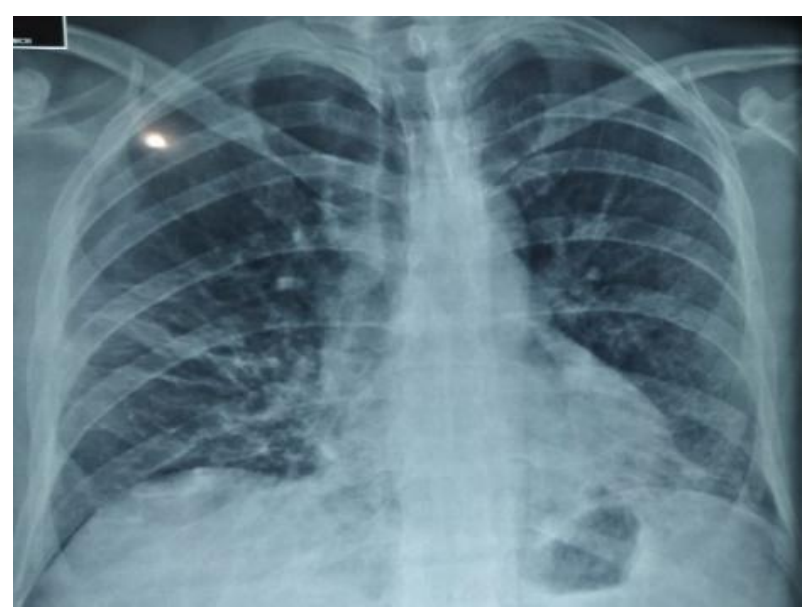

Figure 2 Initial Chest X-ray Source: Coahuila Laboratories

\section{Methodology}

This is a quantitative, longitudinal and prospective case report. The study was carried out in the facilities of the Pulmonary Physiotherapy area of Grupo de Rehabilitación Integral Sinergia, located at Tulum 222, Bosques del Mineral, Pachuca de Soto Hidalgo.

The time dimension corresponds to: March 15 to August 3, 2021. Twenty-four sessions were attended, distributed as follows: 14 sessions three times a week, 10 sessions twice a week.

The main variable identified as: Medical Research Council (mrc) Dyspnea Scale to assess dyspnea in activities of daily living and Airways Questionnare 2D (AQ20) Quality of Life Questionnaire, to identify aspects related to the results of the application of a Pulmonary Physiotherapy Program, based on Respiratory Exercises, Physical Conditioning Exercises and Peripheral Muscle Strengthening Exercises.

VÁZQUEZ-CHACÓN, Verónica, SÁNCHEZ-BARRERA, Eréndira an CHIIO-AUSTRIA, Rosa María. Results of the application of pulmonary physiotherapy in a 38-year-old post-COVID-19 patient after severe pneumonia and type 2 diabetes mellitus. Journal of Physiotherapy and Medical Technology. 2021 
The scales used for the measurement of variables were nominal (Medical Research Council (MRC) Dyspnea Scale), ordinal scale for the classification of clinical form. Interval scale for the Quality-of-Life Questionnaire. The method of data collection was by observation and questionnaire. Informed consent was given for the publication of the present investigation. The patient was trained to perform the respiratory exercises, peripheral muscle strengthening and physical conditioning.

\section{General objective}

The general objective is to create a Pulmonary Physiotherapy Program to achieve that the patient with severe or severe post covid-19 disease with pulmonary compromise and, with oxygen supplementation, reaches his maximum functional capacity, at the same time, facilitating the maximum degree of autonomy and improvement in the health-related quality of life.

\section{Specific objectives}

The specific objectives are listed below.

To decrease the sensation of dyspnea as much as possible.

- Improve ventilatory mechanics, oxygenation and decrease supplemental oxygen.

- $\quad$ Increase respiratory muscle strength.

- Promote functional independence through improvement in cardiopulmonary capacity.

- Evaluate the impact of the program by means of a quality-of-life assessment scale.

The process included: assessment of the 6minute walk, respiratory function tests (spirometry, carbon monoxide diffusion, maximum respiratory pressures), respiratory functional check-up (gas exchange, pulmonary mechanics, flowmetry, forcimetry, oxygen desaturation test, oxygen titration test), which provide us with quantitative values of the respiratory system.
The signature of informed consent was requested, the patient was trained to perform pulmonary therapeutic exercises, the resources used in this research oversaw the researchers, the supervision of the implementation of the Pulmonary Physiotherapy Program oversaw Ms. Verónica Vázquez Chacón, the process is described below:

The following is the approach taken through the application of the Pulmonary Physiotherapy Program. Graphic 1.

For the design of the Pulmonary Physiotherapy program, the paraclinical studies were carried out, the WHO Global Strategy on Diet, Physical Activity and Health was taken into account, as well as: Interim Algorithms for the care of COVID-19, recommendations for Pulmonary Physiotherapy of the ATS/ERS, "Guide for Diagnosis and Treatment of COVID19 (version 7. 0)" from the Health Commission of the People's Republic of China, Spanish Society of Pneumology and Thoracic Surgery, Association of Respiratory Care Physiotherapists in the United Kingdom and Secretary of Health Mexico.

The techniques applied will be shown below:

\section{Active mobilization}

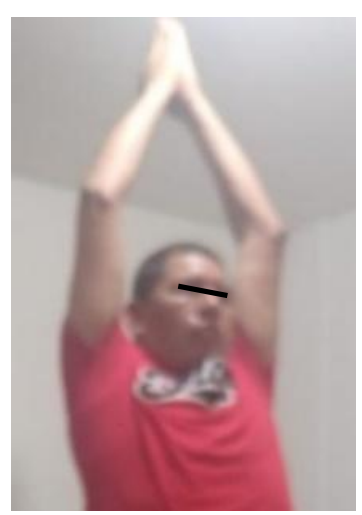

Figure 3 Active mobilization to flexion of upper limbs Source: Own elaboration 
Pulmonary physiotherapy program

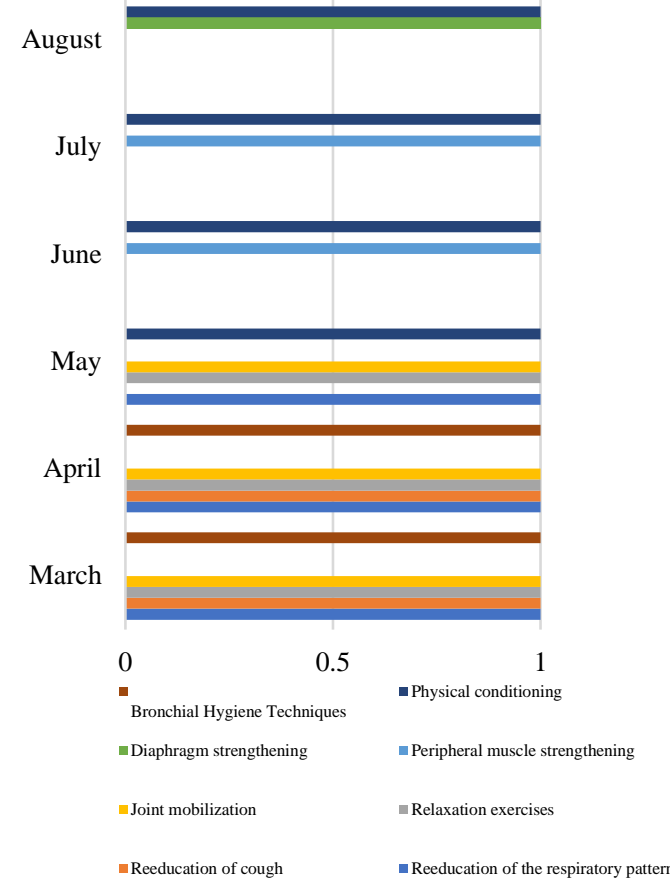

Graphic 1 Pulmonary physical therapy program

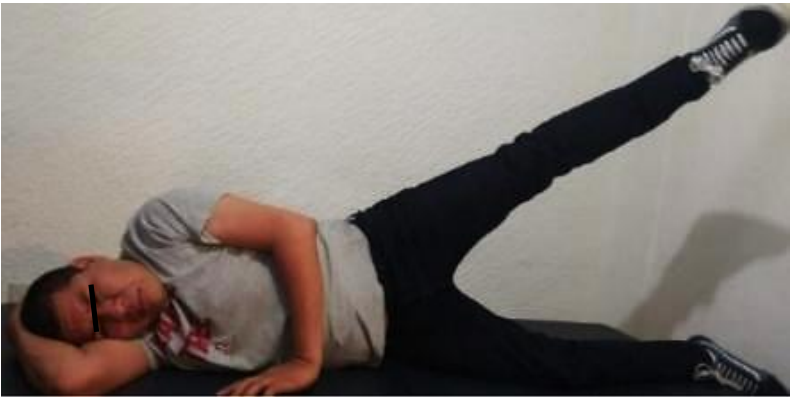

Figure 4 Active mobilization of lower limbs, abduction Source: Own elaboration

\section{Relaxation exercises}

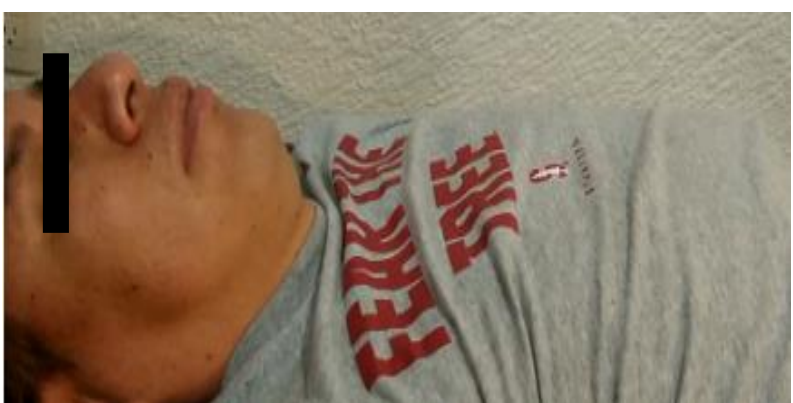

Figure 5 Relaxation exercises Source: Own authorship

\section{Strengthening of peripheral musculature}

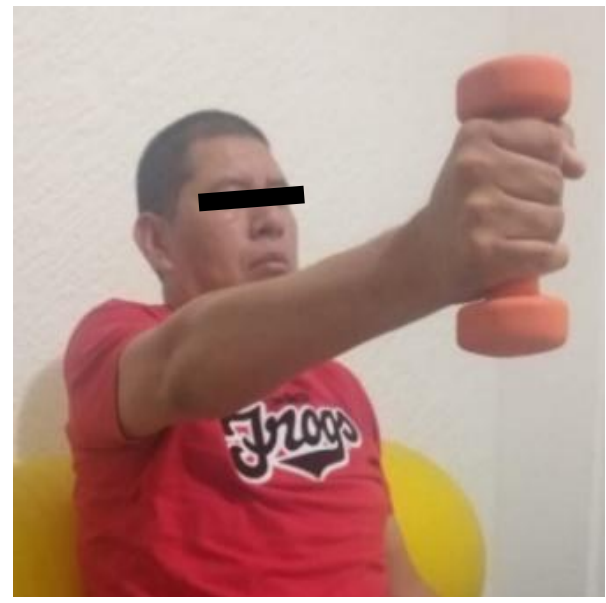

Figure 6 Muscular strengthening of upper limbs Source: Own elaboration

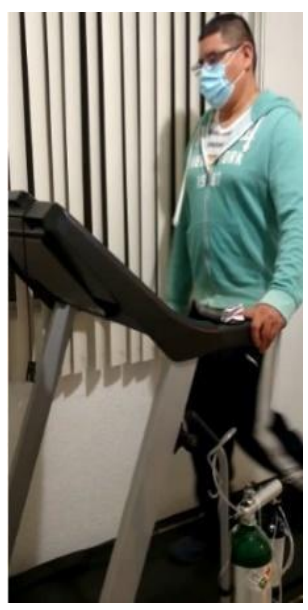

Figure 7 Physical conditioning Source: Own elaboration

Strengthening of respiratory muscles Treshold ${ }^{\circledR}$

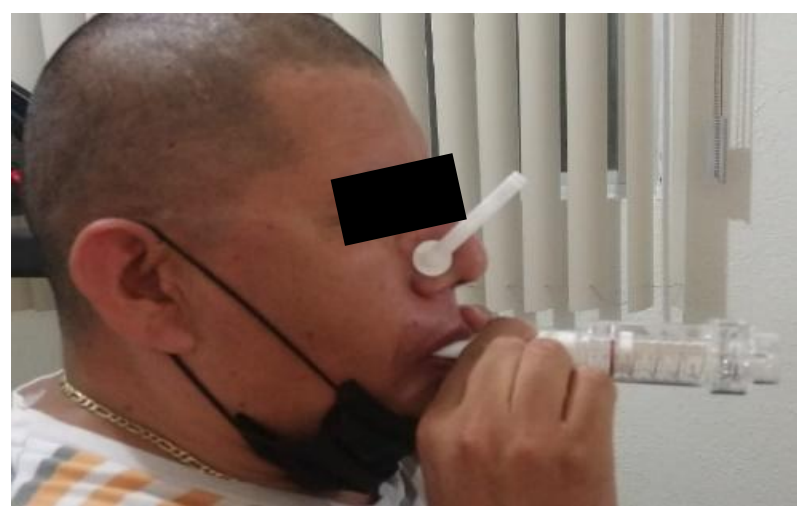

Figure 8 Strengthening of respiratory muscles Treshold®. Source: Own elaboration 


\section{Results}

Regarding the results of the Medical Research Council (MRC) Dyspnea Scale Graph 2. to assess dyspnea in activities of daily living.

The results with respect to Airways Questionnare 2D (AQ20) Quality of Life Questionnaire 13], to identify aspects related to the results of the application of a Pulmonary Physiotherapy Program, with respect to the Quality-of-Life Questionnaire, improved by $35 \%$.

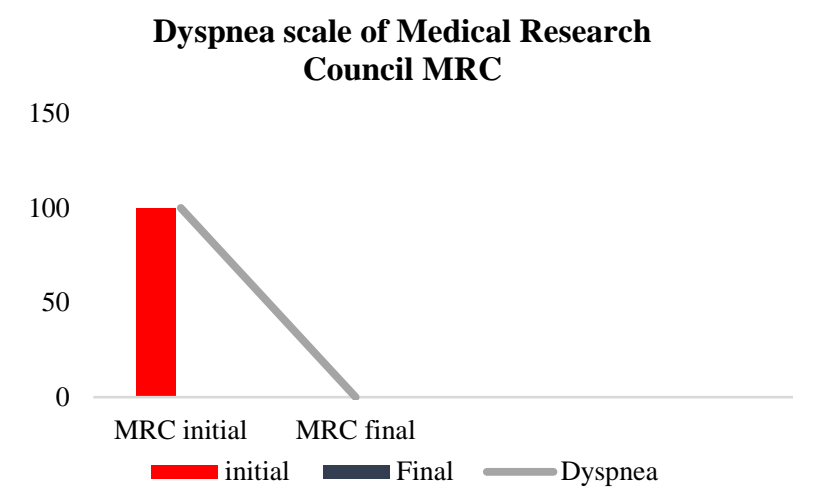

Graphic 2 Dyspnea Scale of the Medical Research Council MRC

Source: Own elaboration

\section{6 minute walk}

150

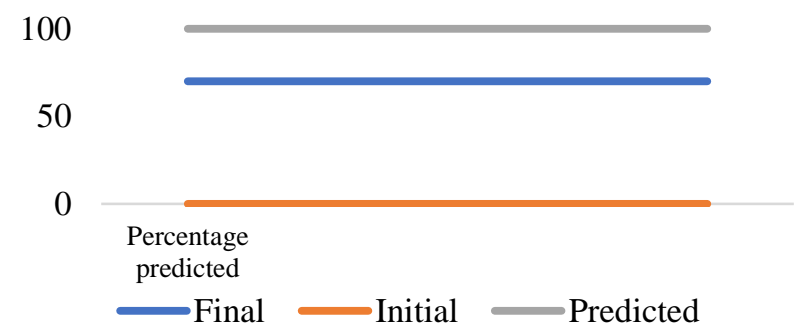

Graphic 3 Percentage of 6-minute walk Source: Own elaboration

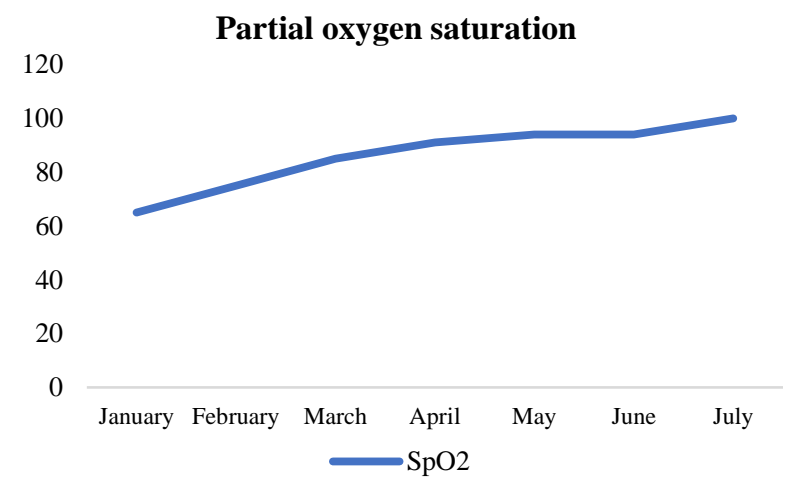

Graphic 4 Partial oxygen saturation Source: Own elaboration

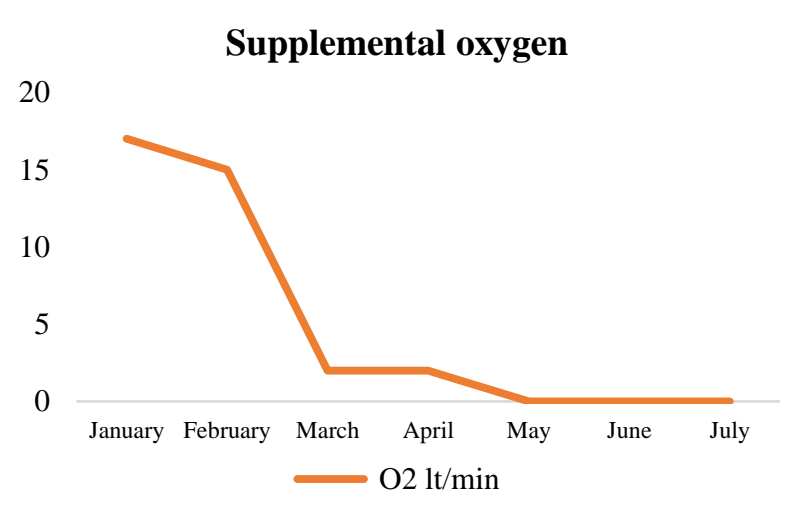

Graphic 5 Use of supplemental oxygen 1t/min Source: Own elaboration

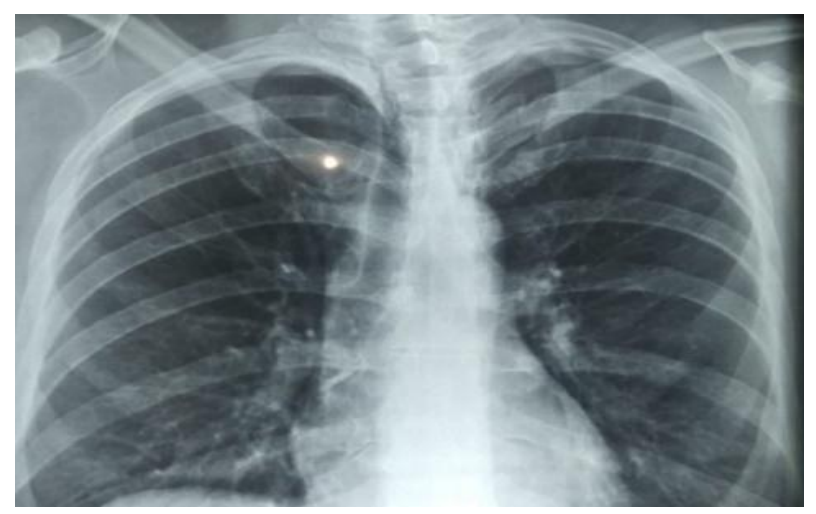

Figure 9 Final Chest X-Ray

Source: Laboratorios Coahuila

The evaluation of the 6-minute walk resulted in a final result of $70 \%$ of the expected distance covered in meters, with environmental conditions of temperature: $20.8^{\circ} \mathrm{C}$, humidity of $53 \%$ and PB of 576 MMHG. Graph 3. No supplemental oxygen, $\mathrm{FiO} 2$ at $21 \%$, respiratory function tests (Spirometry: normal functional pattern, carbon monoxide diffusion, normal transfer pattern, maximal respiratory pressures, Pimax $81 \%$, Pemax $81 \%$ ), respiratory functional check up (Gas exchange, pulmonary mechanics: normal functional pattern, flowmetry, 800 $\mathrm{ml} / \mathrm{min}$, forcimetry: respiratory muscle strength preserved, oxygen desaturation test: positive with high intensity exercise).

\section{Acknowledgement}

The authors would like to thank the patient for his collaboration in the present investigation.

\section{Conclusions}

The benefits were:

- Reduction of dyspnea (100\%) and supplemental oxygen utilization (100\%). Graphics 4 and 5. 
Improved functional capacity for physical activity: $71 \%$.

Improved health status (oxygenation, partial oxygen saturation $35 \%$ and ventilatory mechanics (normal), respiratory muscle strength 18\%) and quality of life $35 \%$.

\section{References}

1) Pérez AMR, Gómez TJJ, Dieguez GRA. Características clínico-epidemiológicas de la COVID-19. Revista Habanera de Ciencias Médicas. 2020;19(2):1-15.

2) Resumen técnico sobre coronavirus COVID-19. Gobierno del Estado de Hidalgo. Página Web. https://coronavirus.hidalgo.gob.mx/

3) Reporte diario Covid-19. 25 de julio 2021. Gobierno de México. Página Web. https://coronavirus.gob.mx/

4) Casos acumulados América. OMS. Página Web. https://paho-covid19-responsewho.hub.arcgis.com/

5) Peralta, G., Carozzo, T., Sierra, M., \& Bu, E. (2020). Enfermedad por coronavirus (COVID-19): la pandemia según la evidencia actual. Innovare: Revista De Ciencia Y tecnología,9(1), 15-27. https://doi.org/10.5377/innovare.v9i1.9657

6) Tolosa Cubillos Jorge M. et al. Propuesta de un protocolo de rehabilitación pulmonar en pacientes supervivientes de covid-19. Revista Med. 3030. Vol 28 (2) https://doi.org/10.18359/rmed.5303

7) Recomendaciones de ejercicios respiratorios para personas mayores en recuperación de COVID-19. Secretaría de Salud. Instituto Nacional de Geriatría. http://www.geriatria.salud.gob.mx/descarg as/publicaciones/Recuperacionrespiratoria-COVID-19_14-05-2020.pdf

8) Tarazona-Fernández, Augusto, RauchSánchez, Erik, Herrera-Alania, Orlando, \& Galán-Rodas, Edén. (2020). ¿Enfermedad prolongada o secuela pos-COVID-19?. Acta Médica Peruana, 37(4), 565570. https://dx.doi.org/10.35663/amp.2020. 374.18669
9) Sociedad Española de Neumología y Cirugía Torácica SEPAR. Fisioterapia Respiratoria en el manejo del paciente con Covid-19 Recomendaciones Generales. Versión 1.0. (2020). Svmerf. Com

10) Algortmos interinos para la atención del Covid-19. Instituto Mexicano del Seguro Social. Gobierno de México. 2021. http://educacionensalud.imss.gob.mx/es/sys tem/files/Algoritmos_interinos_COVID19_ CTEC.pdf

11) Recomendaciones para el tratamiento de la afección por SARS-Cov2, agente causal de COVID-19. Versión 6 de julio 2020. https://coronavirus.gob.mx/wpcontent/uploads/2020/07/Recomendaciones _para_tratamiento_SARS-CoV2.pdf

12) Guía clínica para el tratamiento de la COVID-19 en México, Consenso interinstitucional versión 02 de agosto 2021. https://coviduti.salud.gob.mx/ecsmc/docs/ GuiaTx_COVID19_Consenso_2021.08.02. pdf

13) Vinaccia Alpi, Stefano, \& Riveros Munévar, Fernando, \& Quiceno Sierra, Japcy (2017). Análisis exploratorio del Airways Questionnaire 20 (AQ20) en pacientes colombianos con enfermedad pulmonar obstructiva crónica. Revista Americana de Medicina Respiratoria, 17(1),83-89.[fecha de Consulta 11 de Agosto de 2021]. ISSN: 1852-1630. Disponible en: https://www.redalyc.org/articulo.oa?id=38 2150406009

14) Reyes Sanamé Félix Andrés, Pérez Álvarez María Luisa, Alfonso Figueredo Ernesto, Ramírez Estupiñan Mirtha, Jiménez Rizo Yaritza. Tratamiento actual de la diabetes mellitus tipo 2. ccm [Internet]. $2016 \mathrm{Mar}$ [citado 2021 Ago 11] ; 20( 1 ): 98-121. Disponible en: http://scielo.sld.cu/scielo.php?script=sci_ar ttext\&pid=S156043812016000100009\&lng=es. 